\title{
Austrian foreign policy 1995-2015
}

\author{
Helmut Kramer ${ }^{1, *}$ \\ 1 Institut für Politikwissenschaft, Universität Wien, Austria \\ * E-Mail: helmut.kramer@univie.ac.at
}

\begin{abstract}
During the past 20 years, Austria's foreign policy has undergone far-reaching changes as a consequence of Austria's membership in the European Union. Austria's entry into the European Union broadened its foreign policy agenda: it became involved in a wide range of international issues and in the economic and political positions and bargaining processes of the EU in the international system. On the other hand, EU membership placed considerable constraints on Austria's formerly independent national foreign policy, especially on Austria's neutrality. This article gives an overview of the development of Austrian foreign policy since 1995, analyzing the developments leading from an active foreign policy profile in the I970s and I980s to a more passive, reactive foreign policy after entry into the EU. The main factors responsible for this development are a general weakening of the pro-active political approach in Austria's EU policy and in international affairs, continued cuts in the Austrian foreign service budget, and the growing impact of the trend towards renationalization and provincialisation in domestic politics.
\end{abstract}

\section{Keywords}

Austria, foreign policy, EU membership, renationalization, provincialisation

\section{Österreichs Außenpolitik 1995-2015}

\section{Zusammenfassung}

Die österreichische Außenpolitik wurde durch den EU-Beitritt Österreichs im Jahre I995 wesentlich umgestaltet: Auf der einen Seite wurde die außenpolitische Agenda Österreichs durch die Involvierung in die Positionen und Verhandlungsprozesse der EU wesentlich ausgeweitet. Auf der anderen Seite wurde durch die Mitgliedschaft in der EU die frühere unabhängige Außenpolitik des neutralen Österreichs wesentlich eingeschränkt. In dem Aufsatz wird ein Überblick über die Entwicklung der österreichischen Außenpolitik seit 1995 gegeben, in der die Tendenz zu einer Abschwächung der früheren pro-aktiven Außen- und Vermittlungspolitik auf eine ambivalente Politik in der EU, auf die einschneidenden finanziellen Kürzungen im Bereich des diplomatischen Dienstes und der internationalen Solidarleistungen Österreichs sowie auf den gesamtgesellschaftlichen Trend zur Renationalisierung und Provinzialisierung zurückgeführt wird.

\section{Schlüsselwörter}

Österreich, Außenpolitik, EU Mitgliedschaft, Renationalisierung, Provinzialisierung

The author has declared that no competing interests exist. 


\section{Introduction}

In this essay on the development and the changes in Austrian foreign policy in the period 1995-2015 Part I discusses the overall impact of Austria's membership in the European Union (EU) in the field of Austria's foreign and international policy. Part 2 gives an overview of Austria's difficulties in finding a steady pace and a constructive attitude in its general foreign policy approach to the EU, as well as its failure to fulfill the expectations to act as mediator in the EU enlargement process in Eastern Europe. Part 3 analyzes the stagnation and reduction in the funds necessary for an effective foreign policy role, the organizational crisis of the Foreign Ministry - which in 2007 changed its name from Federal Ministry for Foreign Affairs to Federal Ministry for European and International Affairs (BMEA) and then, in 2014, to Federal Ministry for Europe, Integration and International Affairs (BMEIA) and of Austria's diplomatic representation system as well as Austria's dismal record in the field of development cooperation and international solidarity contributions. Part 4 discusses the Austrian government's role in and responsibility for the general tendency to de-activate Austrian foreign policy as well as the impact of domestic policy on Austria's foreign policy in a societal process of increasing provincialization and renationalization. In the Conclusion (Part 5), we refer to recent attempts to reactivate Austrian foreign policy within the context of the structural problems posed by political and financial impediments on an active foreign policy profile.

\section{Austria's foreign policy in the process of transformation from a nation to a member state}

During the past 20 years, Austria's foreign policy (Gehler 2005; Kramer 2006; Alecu de Flers 2012) has undergone far-reaching changes due to Austria's entry into the European Union (EU) and its transformation from a nation state to a member state. This enabled Austria to considerably widen its foreign policy agenda, becoming involved in a broad range of international issues and participating in external economic relations and the international bargaining processes of the $\mathrm{EU}$ on pressing global questions such as climate change and development aid. As a member of the EU, Austria gained political weight in its international standing, both in Europe and in its role in global affairs and in the United Nations. Through its membership of the EU, Austria gained "additional opportunities to become an active international political player in the Balkan states" (Jandl 2015, 236, translation by the author), a region in which it had already been much involved in the early I990s in the context of the breakdown and dismemberment of Yugoslavia. Austria's geographical proximity, intensive historical and cultural connections, its strong position in the economic sphere, together with the diplomatic skills of Austrian diplomats such as Wolfgang Petritsch and Albert Rohan in representing the $\mathrm{EU}$ in important functions, and the active military participation in the EU and UN peacemaking missions in Kosovo and Bosnia-Herzegovina enabled Austria to play an important and respected role in EU attempts to reduce and put an end to the conflicts in this region and to initiate a process of EU enlargement through the former communist countries in Southeast Europe.

Austria's entry into the EU also had a positive and helpful influence in enhancing Austria's traditionally active role in the UN and the opportunity to host one of the four UN headquarters in Vienna. There were distinct advantages to participation in UN affairs as a member of a political bloc which represented the most loyal partner of the UN in matters of UN-funding as well as in the international initiatives of the UN in the field of worldwide peacemaking and social and economic development.

Furthermore, Austria was supported by its EU partners when it sought to obtain (against strong competition from Turkey and Iceland) a seat as a nonpermanent member of the UN Security Council (SC) in 2009 and 20IO, in which role it initiated SC resolutions in the field of human rights and in the defence of civilians in military conflicts. Austria was also quite active in the field of disarmament (see Kmentt 2016) and in May 20II was elected to the Human Rights Council by the UN General Assembly. That same year, Austrian diplomat Thomas Mayr-Harting was appointed Head of the EU delegation to the UN in New York (Troy 20I3; BMEIA 20II).

At the same time, membership in the EU placed considerable constraints on Austria's formerly independent and largely autonomous national foreign policy. Important foreign policy and security issues now had to be interpreted and handled as questions and matters of "European internal policy". Austria had to adapt its foreign policy, both in terms of specific issues and in accordance with the obligation to increase coordination and consultation in diplomatic relations within the framework of the EU's Common Foreign and Security Policy (CFSP), a political process which - it must be added - is still mainly of an intergovernmental nature and dominated by the particular interests of the big EU member states: France, Germany and Great Britain (Alecu de Flers 2012, If.; Lehne 2015).

One of the most significant consequences of EU membership affecting and constraining Austria's formerly independent national foreign policy positions was the weakening of the political relevance and the narrowing of the scope of application of 
Austria's neutrality. This process of adapting Austria's foreign policy and security policy to the foreign policy positions of the EU had already set in during the period before 1995, when the Austrian government began to intensify formal contacts with Brussels and with the foreign ministries of the EC/EU countries, and to adapt its foreign policy positions to those of the EU. This can be shown in the convergence of positions when Austria was faced with the demands of Slovenia and Croatia for national independence in the context of the breakup and dismemberment of Ex-Yugoslavia in I99I and 1992 and in the United Nations, where "Austria's voting behavior approximated the EC/EU majority line from the early I990s onwards" (Alecu de Flers 20I2, IO4f.; also Luif 1995).

The basis and foundation of Austria's neutral status - which had since 1955 constituted the conceptual and principled fundament of its active foreign policy - had already lost some of its substance and international legitimacy by the end of the Cold War. Then, when Austria joined other European neutrals in imposing sanctions decided by the UN Security Council against Iraq in 1990/1991, there was a clear change from the former "integral neutrality" interpretation (encompassing economic and political neutrality) to a "differential neutrality", where neutrality was reduced to its military functions (no participation in wars without authorisation of the UN, no military alliance and no stationing of foreign soldiers in Austria). From the very beginning of the negotiations with the European Commission, the Austrian government had great difficulty in reconciling the broad consensus within the population that Austria should keep its neutral status and the demands by Brussels for a full commitment to participation in the CFSP as a precondition for membership. The Austrian government continued to keep to the validity of federal constitutional law on neutrality, but added a provisional clause to its Constitution stipulating that Austria's participation in the CSFP would not be impaired by neutrality. This form of neutrality "doublespeak" (Mayer 42, I44) - on the one hand (re)assuring the population that the EU process of homogenizing national foreign policy and the security policy of EU-member states did not go against the core elements of Austrian neutrality, while at the same time accepting without reservations the expansion of military cooperation within the EU through the Petersberg tasks (humanitarian and rescue tasks, peacekeeping and providing combat forces in crisis management, including peacemaking tasks) decided at the European Council of Amsterdam (1997) and the introduction of EU Battlegroups (2004), undermined the credibility and relevance of Austrian neutrality within the context of the EU and in terms of global policy (Alecu de Flers 2012, 94ff.; Roithner 2015).
During the past 20 years, Austria's foreign policy profile was shaped and influenced not only by Austria's EU membership and the impact of "Europeanisation", i.e., the process by which the national foreign policy of individual EU member states is affected by a common European foreign policy - although in some cases, individual member states can also initiate and influence EU policy (Alecu de Flers/Müller 2012). Austrian foreign policy also found itself having to adapt to systemic changes in the international system, an increase of the number of international actors, and new responsibilities for international organizations. Austria and the member states of the European Union were faced with an increasingly crisis-ridden international system, including climate change, serious financial and economic disturbances and the growing number of refugees from war-torn and poor countries. However, one of the most important factors which changed the active foreign policy profile developed in the I970s and I980s into a more passive, reactive profile was the growing impact of the domestic political context and a strong tendency of renationalization and provincialization in Austrian society. The government as well as the Austrian population - largely influenced by the tabloid press - increasingly viewed and debated international issues and foreign policy matters through a narrow lens of national interests and party politicking, gradually eroding the willingness to continue the pro-active foreign policy and global perspective expounded by Bruno Kreisky and Alois Mock (Kramer 20I0).

\section{The weakening of a pro-active political approach in Austria's EU policy}

The hollowing out of Austria's active interpretation of its neutrality - from the formulation contained in its EU membership application letter in July 1999, in which it declared its willingness "to continue its neutrality as a specific contribution to the maintenance of peace and security in Europe" - leading to the increasingly vague and opportunistic stance in the interpretation and application of Austrian neutrality must be seen as just one dimension of a general weakening of the pro-active political approach of Austria's EU policy. From the very beginning of the application process, EU membership was seen and promoted by the government mainly in terms of its economic implications and connotations (Gehler 798, Mayer 161; Meyer 2015, 295f.; Böhm 20I4). The Austrian government and other influential societal actors failed to grasp the fact that the transfer of national sovereignty rights to Brussels (especially under the Treaty of Maastricht, ratified in 1993) and the intensification of the Common Foreign and Security Policy meant that the EU had been moving 
in the direction of a political Union, in which the pursuit and the safeguarding of national interests were to be combined with the obligation to act politically to form a kind of "community of solidarity". At the time, the Socialdemocratic Party (SPÖ) and the Conservative Party (ÖVP), which formed the coalition government (1986-2000) more or less abstained from participating in and contributing to the debates on the reform and the future of the EU. This lack of a "distinctive visible role in the formation of European ideas" (Heinrich Neisser in Gehler 205, 948, translation by the author; also Meyer 2015, 294f.) was reinforced and exacerbated by the political trauma and the political isolation caused by the sanctions against Austria implemented by the EU-I4 in February 2000 (Gehler 2005, 904ff.). This lack of political leadership, in not attempting or being able to inform and educate the Austrian population about the political nature and the basic goals of the EU was one of the main causes of the strong current of "Euroscepticism" in Austrian public opinion ${ }^{1}$, which undermined the political legitimacy of the SPÖ and ÖVP and their dominance in the Austrian political system which they had controlled since $1945 .^{2}$

Austria's record in the EU enlargement process of the former communist countries in Eastern Europe, its failure to fulfill EU expectations of Austria playing a positive role in one of the most crucial issues for the future of the EU as a historical political project, is a telling example of the growing tendency of the Austrian government to abstain and retreat in its EU policy from an active political stance and from attempting to contribute "good services" to the international community (in this case the EU). The active neighborhood policy vis-a-vis the communist countries in Eastern Europe through close political, diplomatic, economic and cultural relations and initiatives supporting and fostering the process of detente between East and West, especially in alliance with the other European neutrals in the Conference on Security and Cooperation in Europe (CSCE), had been one of the most important foreign policy achievements in the I960s and I970s (Kramer 2006, 8I4ff. on Austria's role in the CSCE process see Gilde 20I3)

Against this political background, and in view of Austria's extensive historical, political and cultural connections with its eastern neighbors, the European Commission in its official statement regarding Austria's membership ("Avis" August I99I), formulated and expressed the following expectation of Austria's role in the enlargement process of the European Community:

I Only $23 \%$ of the Austrian respondents have a positive image and $4 \mathrm{I} \%$ a negative image of the EU which ranks Austria with Cyprus and Greece at the bottom of the EU-countries (EU average: $37 \%$ positive, $23 \%$ negative) (Eurobarometer 2015, 7).

2 In I995, two thirds of Austrian voters opted for the SPÖ and ÖVP in the parliamentary elections $(66,4 \%)$. In the parliamentary election of 2013 the share of SPÖ and ÖVP fell to $50,8 \%$.
"Furthermore" (apart from the fact that Austria would be a net contributor to the EU Budget; H.K.), "the experiences of a country will be advantageous for the Community, which by its geographical position, its history and by its inherited as well as by its newly developed connections lies exactly in the center of the process in which a new Europe is developing" (quoted in Gehler 2005, 755, translation by the author).

The policy of the Austrian government in the enlargement process leading to an additional 12 member countries in 2004 and 2007 neither lived up to the expectations of the EU nor to those of the Eastern European candidate countries which had hoped that Austria would act as a a bridge and as a kind of political mentor in their application process (Alecu de Flers 2012, $89 \mathrm{f}$. Hinteregger 2008, 272f.). Although Austria's banks and enterprises were actively exploiting the immense opportunities generated by the political upheaval in Eastern Europe in 1989, and invested heavily in the Eastern European countries - Austria being one of the EU countries to profit most from the opening up of East Europe Austria's political support for its eastern neighborhood was lukewarm and highly ambivalent. The Austrian government was critized by leading political figures in Poland and other candidate countries in the East for in the words of the Polish Foreign Minister Wladyslaw Bartoszewsky - the "lack of leadership... and willingness to continue the way of Bruno Kreisky and Erhard Busek. The people in Central and Eastern Europe did not understand why Austria had not acted as an important European mediator" (Der Standard 19.12.1997: translation by the author; Luif 2015).

Domestic policy played an important role in this process, in which "Austria went from its expected role as a 'pacemaker' to that of a 'troublemaker', thus losing credibility among its Eastern neighbors in a reprehensible manner" (Paul Lendvai, in: Die Presse 27.2.or quoted in Gehler 2005, II65, translation by the author). The bilateral disputes on the issue of nuclear power plants near the Austrian border with the Czech Republic and Slovakia and the bitter dispute over the "Beneš decrees" which defined the legal framework for the expulsion of Germans and Austrians by the government of postwar Czechoslovakia were further exacerbated and deepened by the entry of the Freedom Party (FPÖ) in the Austrian government in February 2000. In January 2002, the nationwide referendum against the nuclear plant in Temelin in the South of the Czech Republic, initiated by the FPÖ and heavily backed by the "Kronenzeitung" -Austria's most important tabloid newspaper - was able to muster close to a million signatures. And in response to pressure both from coalition partner FPÖ and the Austrian trade movement and protectionist-oriented sectors of Austrian industry, the ÖVP and chancellor Schüssel decided to opt for a transition period of 7 years 
during which the free movement of labor and services from the new member states were restricted.

"Many chances resulting from the new membership in the EU have been wasted; and Austria still has not found a steady pace and a solid place in the formulation of EU policies" was how the prominent Austrian diplomat Eva Nowotny evaluated the situation (Nowotny 2005 , 39). One of the main reasons why Austria's political record in its two decades of EU membership was not as successful as it could have been, why it failed or had difficulties to find acceptance in important policy issues such as in its Transit Policy is because Austria, unlike the Scandinavian and the Benelux members of the EU did not manage to become part of a stable political bloc in the EU. That Austria found no solid political partners in the EU was besides the consequences of Austria's political isolation induced by the "sanctions" imposed by the EU-I4 in 2000 (Gehler 2006, 974f.) foremost a result of Austria's failure to live up to a supportive political role in the application process of the Eastern countries. The rather desperate and hasty attempt to correct this historical failure by forming a "strategic partnership" (later renamed "regional partnership") with the Eastern European countries in 2003 was met with considerable skepticism by the members of the Visegrad group (Poland, Czech Republic, Slovakia and Hungary) and soon lost relevance (Luif 2015).

\section{Stagnation and reduction in foreign ministry foreign service funding and Austria's deficits in international solidarity payments ${ }^{3}$}

Over the past twenty years, the Austrian Foreign Service has faced a considerable increase in the number and complexity of its tasks and service functions. Most important were the new challenges and obligations stemming from its membership in the EU - Austria held the EU presidency in the second half of 1998 and again in the first half of 2006 - and the new form of European diplomacy created by the establishment of the European External Action Service (EEAS) under the Lisbon Treaty (Sonnleitner 2015, 9 f.). At the same time, Austrian diplomats were also confronted with new developments and issues in the international system, with new actors and new states as well as with the expansion of the activities of the UN, the Organization for Security and Cooperation in Europe (OSCE) and other international organizations. Increased tourism and international travel on the part of Austrian citizens multiplied the need for consular services.

3 The analysis of the staff development within the Federal Ministry for Europe, Integration and Foreign Affairs is based on the annual Foreign and European Policy Reports (1995-2014).
In this context of new tasks and a growing workload for the staff of the Austrian Foreign Service, the continuous reduction of the number of posts in the Austrian Foreign Service led to a progressive deterioration in the working conditions of the diplomats and officials in Vienna and in the embassies and consulates abroad. As Figure I shows, the number of Foreign Ministry staff shrank from 1.616 posts in 1995 to I.160 in 2014 - a reduction of almost a third.

Fig. 1: Austrian foreign ministry staff: 1995-2014

\begin{tabular}{ll}
\hline 1995 & 1.616 \\
\hline 1996 & 1.595 \\
\hline 1997 & 1.582 \\
\hline 1998 & 1.606 \\
\hline 1999 & 1.606 \\
\hline 2000 & 1.489 \\
\hline 2001 & 1.446 \\
\hline 2002 & 1.376 \\
\hline 2003 & 1.374 \\
\hline 2004 & 1.332
\end{tabular}

\begin{tabular}{ll}
\hline 2005 & 1.304 \\
\hline 2006 & 1.287 \\
\hline 2007 & 1.278 \\
\hline 2008 & 1.342 \\
\hline 2009 & 1.307 \\
\hline 2010 & 1.277 \\
\hline 2011 & 1.225 \\
\hline 2012 & 1.169 \\
\hline 2013 & 1.183 \\
\hline 2014 & 1.160 \\
\hline
\end{tabular}

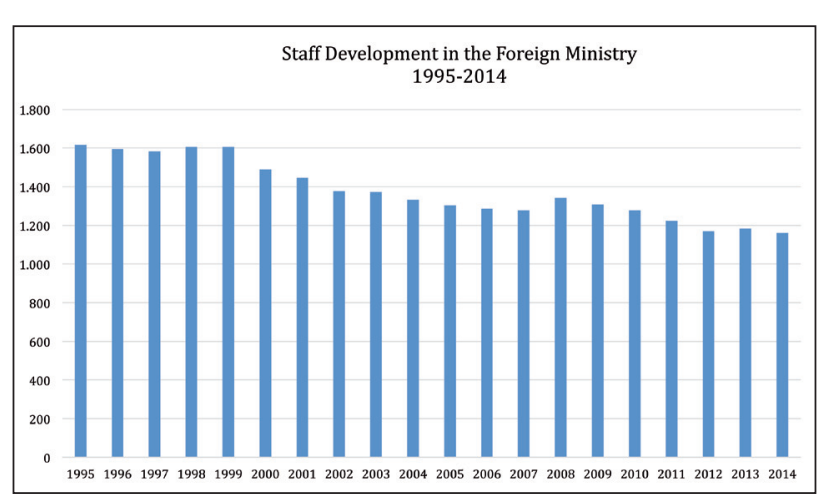

Source: Foreign Policy Reports, BMEIA 1995-2014

At the same time, the Foreign Ministry's budget -the share of staff costs amounts to $50-55 \%$ and to development aid contributions $20-25 \%$ - stagnated as a consequence of the austerity programs of the second half of the I99os and the "zero deficit" policy of the ÖVP-FPÖgovernment in the years 2000-2006. Under the financial and economic crisis the Foreign Ministry's budget was reduced from $€ 435.7$ million in 2009 to $€ 418.8$ million in 20I4. And the outlook for the next years is bleak: under the "Federal Budgetary Framework" for 20162019, the Foreign Ministry will have to reduce its annual budget by $€ 20$ million (Wiener Zeitung, 3.9.2015).

In order to cope with the additional tasks for the Austrian diplomats during the Austrian EU-presidencies in 1998 and 2006 and the presidency of the OSCE in 2000, the Foreign Ministry employed additional temporary 
staff. However, in 2006, the practice of hiring part-time assistance became standard practice, and the number of supporting staff ("Internships"), who work for a year for a minimal salary, went from 27 in 2006 to an astounding 299 in 2014, while the number of new permanent posts steadily decreased. In 20I4, there was no new recruitment for permanent staff posts at all.

This led to a situation where important Foreign Ministry departments are forced to operate with a minimal permanent staff (see Kramer 2013, 47). The serious deterioration in the working conditions of the Foreign Ministry diplomats, who are faced with manifold additional tasks, can also be traced back to the progressive reduction in the number of administrative support staff (i.e. of staff providing administrative services and technical support) in secretariats from 1995 onwards. In I995, the percentage of Foreign Ministry staff working at the diplomatic level ("Diplomatic Staff") was 29.7\%, while officials operating at the support level ("Technical, Clerical and Support Staff") made up 53.3\%. In 2014 the ratio was $35,7 \%$ at the senior level and $44,6 \%$ at the support level. ${ }^{4}$

Budget cuts at the Foreign Ministry have also had quite far-reaching consequences for the operation of Austria's embassies and consulates. The number of diplomats and support staff in Austria's diplomatic representations abroad has been traditionally smaller than those in comparable European countries. According to Eva Nowotny, former Austrian ambassador to the United States "only two EU member states have embassies in Washington that are smaller than the Austrian: namely Cyprus and Malta. The Luxembourg Embassy is of exactly the same size" (Nowotny 2005, 37). Another example of the understaffing of important Austrian diplomatic representations can be seen if we look at the staffing levels of the Permanent Mission of Austria to the UN Headquarters in New York, which consists of II diplomats and 4 administrative assistants (BMEIA 2016) and compare it to the Mission of Sweden to the UN, which has a staff comprising 23 diplomats and I3 administrative assistants (Swedish Ministry of Foreign Affairs 2016). At the UN Mission of Switzerland, a UN member only since 2002, there are 22 diplomats and II administrative assistants (Swiss Federal Department of Foreign Affairs 2016).

In the Foreign Ministry in Vienna, attempts to counteract and alleviate the serious staff shortage produced by the stagnating and dwindling budget have included increasing the number of active Austrian honorary consuls (the number of which has increased from about 200 in the I990s to about 300 in recent years) and by strengthening cooperation with the worldwide network of Austrian trade representatives nominated and

4 At the middle level of the "Consular and Administrative Staff", there was only a slight increase (from I8,0\% in 1995 to $18,9 \%$ in 2010 and to $19,6 \%$ in 2014 . funded by the Austrian Federal Economic Chamber. Nonetheless, a situation where many diplomatic representations have been reduced to one diplomat and a very limited number of additional staff seriously hinders opportunities to promote Austrian foreign policy interests, to support the business activities of Austrian firms and to provide consular services for Austrian citizens travelling abroad. In the words of Albert Rohan, a former General Secretary of the Foreign Ministry: "The recent cuts [in the numbers of staff of the Foreign Ministry, H.K.] mean that we will soon be down to the bare bones. And since there is to be no new recruitment until 20I4, staffing levels will have become so poor by then that many embassies will be using practically all their resources in self-administration" (Profil 8.II.20IO, translation by the author). The few new Austrian diplomatic representations, located mainly in the new EU member countries (Sonnleitner 2015, IIf.) were offset by the closing down or downsizing of other embassies and consulates, especially in Africa and Latin America, thus restraining and reducing political and economic relations with important newly-emerging players in the international system (Kramer 20I3, 48).

The stagnation in and reduction of the Foreign Ministry budget also limit and restrain Austrian initiatives and activities in the field of international mediation and in humanitarian projects. While countries such as Norway and Switzerland have in recent years greatly expanded their efforts in facilitation and mediation in violent conflicts and civil wars (Switzerland's Federal Department of Foreign Affairs established a well-staffed Human Security Division which spent in 20II more than $€ 70$ million for mediating processes and peacebuilding in Africa, the Middle East and Southeast Europe, Aussenpolitischer Bericht der Schweiz 2013, IOI6f.). Austria's Foreign Ministry has practically no financial resources to invest in acting as a neutral conflict mediator in conflict facilitation, peacebuilding processes and humanitarian projects (Kramer 2013, 53). In the deteriorating budgetary situation, projects and activities started by Foreign Minister Ursula Plassnik in 2004 in the field of "Women and Development" had to be reduced in scope and subsequently cancelled altogether. And it seems to be no accident that Austria's positive role in the field of disarmament and non-proliferation, Rule of Law and Human Rights in the United Nations refer to activities, initiatives and support of resolutions which do not burden the budget of the Foreign Ministry.

Furthermore, the budget cuts deepened the rift between the official rhetoric claiming to support the goals of poverty reduction in developing countries and peacemaking efforts on the part of the UN and other international organizations and the very meagre financial contributions by Austria to fulfil its international solidarity obligations. And this not only in terms of Austria's 
dismal performance in the field of Official Development Cooperation (ODA), where Austria both quantitatively $(0,27 \%$ of Gross National Income in 20I3) and qualitatively (priority countries, tied aid) lags significantly behind other EU countries (see Lightfoot/Obrovsky in this issue). The lack of international solidarity in terms of financial contributions - a foreign diplomat once ironically described Austria's UN developmental policy with the words "big heart, open mouth, tight purse" - is also reflected in the scarce support Austria is willing to give to the programs of the special organizations of the UN in the field of international aid, to combat famine and epidemic diseases in developing countries, to provide aid to refugee camps in Africa and in the Middle East or for projects of the UN Climate Fund in assisting developing countries to counter the effects of climate change. To give two examples: the annual contribution to the United National High Commissioner for Refugees (UN$\mathrm{HCR}$ ) by Austria in the period 2010-20I4 amounted to $€ 0.33$ per capita, while Switzerland spent Io times as much $(€ 3.87$ per capita) and Sweden more than 30 times as much (€IO,49 Euro per capita)(UNHCR 2OI4); and the Austrian pledge to the Green Climate Fund of the UN is US $\$ 26,8$ million, while comparable European countries like Norway donated $€ 257,9$ million and Sweden, $€ 58$ I , 2 million (Climate Funds Update 2015, 2).

\section{The Role of government and of domestic politics in the deactivation in Austrian foreign policy}

"It is a bitter truth that, in recent years, the Foreign Ministry has become a kind of orphan in Austrian politics without money, without concepts, without vision" (Paul Lendvai in Salzburger Nachrichten 8.I.2OI3, translation by the author). However, not all the blame and responsibility for the continuous reduction of funds can be laid at the feet of the Foreign Ministry and the Foreign Minister: that there were so few resources available to implement Austria's international policy was the responsibility of the entire government and its leading political figures, the Chancellor and the Vice Chancellor. The budget cuts in the Foreign Ministry were a result of financial and economic measures taken by the government, caused by its austerity policy to meet the convergence criteria for the EU economic and monetary union (EMU) in the late I990s, by the "zero deficit" budgetary philosophy of the ÖVP/FPÖ government (2000-2006) and by the effects of the worldwide international financial and economic crisis which began in 2008. And the budget cuts in the Foreign Ministry (which in comparison were greater than in other ministries) were accepted and implemented by Foreign Ministers who combined the post of Foreign Minister with the position of Vice Chancellor in the SPÖ-ÖVP coalition governments and were also Chairman of their party, as was the case with Wolfgang Schüssel (1995-2000) and Michael Spindelegger (2008-2013).

An analysis of the factors and developments which led Austria to have an increasingly reactive and inwardlooking political profile in terms of foreign policy and international affairs must furthermore take into consideration the considerable change in the mode of foreign policy decision-making in the EU since the I990s. There was the continuous institutional buildup of the EU Common Foreign and Security Policy (CFSP), with the enlargement of the competences of the High Representative for Foreign Affairs and Security Policy and the creation of the European External Action Service (EEAS), the increasing influence of prime ministers and the European Council as well as a more important role taken on by other ministries (especially of the Ministry for Finance and Interior, see Sonnleitner 2015, I0), which reduced the overall influence of foreign ministers and of the diplomatic class. However, the most significant development in this process was the fact that prime ministers and chancellors have been - as argued persuasively in a recent essay by Stefan Lehne (who left the Austrian diplomatic service to become a consultant with the Carnegie Foundation Europe) "taking over EU Foreign Policy" (Lehne 2015). The last step in this process was brought about by the Lisbon Treaty of 2007, which stipulated that foreign ministers would lose their right to participate in the meetings of the European Council. "Ever since the creation of the European Council in I975, foreign ministers have had a seat at the table, but this right was taken away in the Lisbon Treaty - a serious loss of influence and a major blow to their prestige" (Lehne 2015, 8).

This assumption of the leadership role in EU foreign policy by the European Council and the prime ministers and heads of the EU member states had far-reaching consequences for the substance and the political quality of foreign policy decision-making in the EU. Since prime ministers and the European Council usually operate "under severe time constraints and handle(s) foreign policy almost exclusively in a crisis-management context" (Lehne 2015, I), the importance of medium- and long-term strategic thinking in foreign policy, and of the substantive international analysis which had in the past been provided mainly by foreign ministries and by the diplomatic service declined considerably. The negative effects on the quality of foreign policy decision-making are exacerbated by the fact that most of the prime ministers in the EU "have ascended through the ranks of domestic politics and are often not well-versed in foreign policy" (Lehne 2015, 5). With the exception of the prime ministers of the big European member states France, Germany and Great Britain, the cabinets of prime ministers usually comprise only a few diplomatic and for- 
eign policy advisers. However, the main reason that the foreign policy decision-making process in the EU is now increasingly dominated by short-term, reactive attitudes on the part of the heads of the EU member states, is that foreign policy decisions are more and more influenced and dominated by domestic political pressures, by party politics and the media (Lehne 2015, 5f.).

These structural developments in EU foreign policymaking, the waning of the influence of foreign ministers and the increasing dominance of prime ministers and chancellors, as well as the growing impact of domestic politics, have to be taken into account if one wants to explain the change in Austrian foreign policy profile from active international political player to an increasingly reactive and inward-looking attitude in international affairs. In this process of growing renationalization and provincialization, foreign affairs and EU policy are regarded and treated by government simply as an extension of "domestic policy with other means". Important foreign policy decisions - for instance the recalling of the Austrian UN mission from Golan in June 2013, which caused significant damage to Austria's image in the UN, are very much influenced by tabloid newspapers which monopolistically control the media market. There is a deplorable lack of interest and competence in foreign policy and international affairs in the Austrian political parties and in the parliament - as highlighted by the fact that the debates on foreign policy issues are usually shifted to the evening sessions. The government and the political class of the country are woefully neglecting their political leadership obligations task- which would be to persuade and convince the Austrian population that Austria's interests and its future, in a world of the process of increasing globalization and internationalization, require an active foreign policy profile based on adequate financial means for the Foreign Ministry, the foreign service and Austria's international obligations in the field of development cooperation.

\section{Conclusion and outlook}

This trend towards a continuous de-activation of Austrian foreign policy reached its peak in the years around 2013. Michael Spindelegger, who (as mentioned earlier) combined the posts of Foreign Minister with the position of Vice-Chancellor as well as with Chairman of the Conservative Party, was overburdened with domestic policy problems. He missed important foreign policy meetings in Brussels and in New York and reduced his foreign diplomatic travel diplomatic visits to a minimum (see Kramer 20I3). The decision to recall back the Austrian UN contingent from the Golan Heights in June 2013 was, in the words of the retired Austrian general Hannes Philipp, the first commandant of UNDOF (United Na- tions Disengagement Force on the Golan) in the I97os, the "most serious embarassment for Austria's foreign policy" (Die Presse 28.6.20I3, translation by the author) and caused serious damage to Austria's image at the UN.

Spindelegger's young successor at the Foreign Ministry, Sebastian Kurz, „took over a field of rubble“ (Kurier I3.I2.2OI3). The active diplomatic stance of this energetic young politician in promoting the role of Austria (and Vienna) as an international meeting place as demonstrated in the negotiations related to Iran's nuclear atomic policy and the more active role Austria now plays in the EU in the refugee crisis can be seen as signs for an growing consciousness that Austria needs to reactivate its foreign policy (see Kramer 2016). However, the severe structural impediments to an active foreign policy profile in the context of the EU and in the international community still exist: the Foreign Ministry's budgetary situation for the foreseeable future next years is still cause for serious concern, as is the tendency of government, the political class and the population to see foreign policy and international affairs through the prism of domestic politics and through a perspective of renationalization, reinforced by the deformation of Austria's political system caused by a kind of ",tabloid press democracy" (Plasser 2012, also Plaikner 2015).

\section{Literature}

Außenpolitischer Bericht der Schweiz (20I3). Eidgenössisches Department für auswärtige Angelegenheiten, Bern.

Böhm, Wolfgang (2014). Noch immer einsam, in: Die Presse 20.12.20I4.

Climate Funds Update (2015). Heinrich Böll Stiftung, Berlin.

Alecu de Flers, Nicole (2012). EU Foreign Policy and the Europeanization of Neutral states: Comparing Irish and Austrian Foreign Policy, London/New York.

Alecu de Flers, Nicole/Patrick Müller (2012). Dimensions and Mechanisms of the Europeanization of Member State Foreign Policy: State of the Art and New Research Avenues, in: Journal of European Integration, Vol. 34(I), 19-35.

Bundesministerium für Europa, Integration und Äusseres (BMEIA) (I995-20I4). Außenpolitische Berichte I99520I4, Vienna, internet: https://www.bmeia.gv.at/en/ the-ministry/foreign-and-european-policy-report/.

Bundesministerium für europäische und internationale Angelegenheiten (BMEIA) (2OII). Österreich im Sicherheitsrat der Vereinten Nationen 2009/20IO. Bericht des Bundesministers, Vienna.

Bundesministerium für Europa, Integration und Äusseres (BMEIA) (20I6). Permanent Mission of Austria to the United Nations, New York, Vienna. 
Eurobarometer (2015). Public Opinion in the European Union. First Results, Eurobarometer 84.

Gehler, Michael (2005). Österreichs Außenpolitik der Zweiten Republik, Von der alliierten Besatzung bis zum Europa des 2I. Jahrhunderts, 2 Bände, Innsbruck/Vienna/Bozen.

Gilde, Benjamin (2013). Österreich im KSZE-Prozess 1969-1983. Neutrale Vermittler in humanitärer Mission, Munich.

Hinteregger, Gerald (2008). Im Auftrag Österreichs. Gelebte Außenpolitik von Kreisky bis Mock, Vienna.

Jandl, Gerhard (2015). Beginnt der Balkan noch immer in Wien? Betrachtungen zu 20 Jahren österreichischer Balkanpolitik im Rahmen der GASP der EU, in: Andreas Maurer/Heinrich Neisser/Johannes Pollak (Hg.), 20 Jahre EU-Mitgliedschaft Österreichs, Vienna, 235-249.

Kmentt, Alexander (2016). The Development of the International Initiative on the Humanitarian Impact of Nuclear Weapons and its Effect on the Nuclear Weapons Debate, in: International Review of the Red Cross, Vol. I, I-29.

Kramer, Helmut (2006). Strukturentwicklung der Außenpolitik (1945-2005), in: Herbert Dachs u.a. (Hg.), Politik in Österreich. Das Handbuch, Vienna, 807-837.

Kramer, Helmut (20I0). Österreich ist "Hinternational". Zur Stagnation und Krise der österreichischen Außenpolitik, International 20IO, 4-8, internet: $\mathrm{http} / / /$ homepage.univie.ac.at/helmut.kramer/helmut.kramer/Publikationen_files/IntıIo_Kramer. pdf

Kramer, Helmut (2013). Bleibt Österreichische Außenpolitik eine "Draussenpolitik"? Österreich muss mehr in seine internationale Politik investieren, In: International 20I3/IV, 49-54, Internet: https:// homepage.univie.ac.at/helmut.kramer/helmut.kramer/Publikationen_files/INT_4_2OI3_Kramer.pdf. (accessed: 29.6.2016).

Kramer, Helmut (2016). Plädoyer für eine Reaktivierung der Außen- und Neutralitätspolitik Österreichs, In: Thomas Roithner/Ursula Gamauf (eds.): Am Anfang war die Vision vom Frieden. Wegweiser in eine $\mathrm{Zu}-$ kunft jenseits von Gewalt und Krieg. Festschrift zum 90. Geburtstag von Gerald Mader, Vienna, 343-356.

Lehne, Stefan (2015). Are Prime Ministers taking over EU Foreign Policy? Carnegie Endowment for International Peace, February, Brussels.

Luif, Paul (2005). On the Road to Brussels: the political dimension of Austria's, Finland's and Sweden's accession to the European Union, Vienna.

Luif, Paul (2015). Mitteleuropa und Österreich in der Europäischen Union, in: Michael Gehler/Paul Luif/Elisabeth Vyslonzil (eds.): Die Dimension
Mitteleuropa in der Europäischen Union. Geschichte und Gegenwart, Hildesheim, 279-315.

Nowotny, Eva (2005). Austrian Foreign Policy in Historical Context, in: Contemporary Austrian Studies, Vol. I4, 25-39.

Mayer, Thomas (2014). Frei in Europa. Österreich rückt ins Zentrum eines turbulenten Kontinents, ViennaGraz-Klagenfurt.

Meyer, Sarah (2015). Wer kämpft noch für Europa?, in: Andreas Maurer/Heinrich Neisser/Johannes Pollak (Hg.), 20 Jahre EU-Mitgliedschaft Österreichs, Vienna, 293-306.

Plaikner, Peter (2015). Im Wechselspiel des Populismus. Medien alsTransporteure und Turbos deröffentlichen Meinung, in: Andreas Maurer/Heinrich Neisser/ Johannes Pollak (Hg.), 20 Jahre EU-Mitgliedschaft Österreichs, Vienna, 262-276.

Plasser, Fritz (Hg.). Erfolgreich Wahlkämpfen. Massenmedien und Wahlkämpfe in Österreich, Wien.

Roithner, Thomas (2015). Das Missverhältnis von zivil und militärisch. Das Exempel Österreich. in: Wissenschaft und Frieden, Vol. 33(3), 47-49.

Sonnleitner, Sandra (2015). Austrian Bilateral Diplomacy in the Context of EU Membership - Case Study on the Austrian Ministry of Foreign Affairs, EUFORPOL Working Paper 7, Bratislava.

Swedish Ministry of Foreign Affairs (2016). The Permanent Mission of Sweden to the UN Mission New York.

Swiss Federal Department of Foreign Affairs (2016). The Permanent Mission of Switzerland to the UN Mission New York.

Troy, Jodok (ed.) (2013). Im Dienst der internationalen Gemeinschaft - Österreich in den Vereinten Nationen, Innsbruck.

\section{Author}

Helmut Kramer was from 198I-20I6 Professor of International Politics at the Institute of Political Science at the University of Vienna. His research and publications are in the field of Austrian Foreign Policy and EU Policy, the political and economic development and the process of EU-Association of the Westbalkan States, the role of Political Science and Intellectuals in the political system. 
